\title{
PENGARUH TRANSAKSI ELECTRONIC BANKING TERHADAP FEE BASED INCOME PADA PT BANK CIMB NIAGA, Tbk PERIODE 2014 - 2017
}

\author{
Oliviani Rizki Arisanti *) \\ Prihatiningsih **)
}

\begin{abstract}
This study aimed to knowing the effect of electronic banking transactions to fee based income PT. Bank CIMB Niaga, Tbk. The strategy that was used in this research was associative strategy or relations effect. The method was used in this research was ex post de facto. The subject in this research is PT. Bank CIMB Niaga, Tbk from the merger company that is between Bank Niaga with the Lippo Bank until now. Sample that was used is the e-banking transactions and fee based income of PT. Bank CIMB Niaga, Tbk for 4 years (year 2014-2017). The variable that was researched covered the free variable that is the e-banking transactions. Whereas the variable was tied was fee based income. This study was carried out by using the analysis technique of simple linear regression and for the data processing used spss the version 16,0. Were based on results of the testing of the hypothesis $\alpha=5 \% d f=n-k=2$ was received $t_{\text {table }} i s 4.302$ and $t_{\text {counted }}$ is 11,855 ( $t_{\text {counted }}>t_{\text {table }}$ ) so the conclution $H_{0}$ was refused and $H_{a}$ was accepted, that means there is positive and significant influence the e-banking transactions to fee based income PT. Bank CIMB Niaga, Tbk.
\end{abstract}

\section{Keywords $\quad$ : E-Banking, Fee Based Income}

*) Mahasiswa Tugas Akhir Prodi Keuangan dan Perbankan, Jurusan Akuntansi, Politeknik Negeri Semarang

**) Dosen Jurusan Akuntansi, Politeknik Negeri Semarang

\section{PENDAHULUAN}

\section{Latar Belakang Masalah}

Selama beberapa tahun terakhir ini, bank komersial telah memperkenalkan sistem perbankan berbasis internet untuk meningkatkan operasional dan mengurangi biaya. Internet banking merupakan salah satu bentuk produk jasa yang mulai banyak ditawarkan oleh bank - bank komersial di Indonesia. E-Banking adalah salah satu produk dunia pebankan yang menerapkan sistem informasi akuntansi yang terkomputerisasi. E-Banking terdiri dari ATM (Automated Teller Machine), SST (Self Service Terminal), CDM (Cash Deposit Machine), Phone banking, SMSBanking, dan Internet Banking. Transaksi perbankan dapat dilakukan kapan dan dimana saja tanpa dibatasi tempat dan waktu. Di Indonesia Pengaturan internet banking tidak terlepas dari Undang Undang Perbankan Nomor 7 Tahun 1992 beserta undang - undang perubahannya, yakni Undang - Undang Nomor 10 Tahun 1998. Bagi bank memberikan pelayanan yang mudah, cepat dan murah merupakan celah atau peluang bisnis. Mereka tetap dapat memperoleh fee dalam layanan ini. 


\section{Rumusan Masalah}

Berdasarkan latar belakang masalah di atas, dapat dirumuskan masalah dalam penelitian ini adalah adanya perbedaan hasil penelitian terdahulu tentang Electronic Banking dan kenaikan persentase penggunaan Electronic Banking yang semakin menurun. Berdasarkan rumusan masalah tersebut, maka disusunlah pertanyaan penelitian sebagai berikut:

a. Apakah transaksi Electronic Banking berpengaruh terhadap Fee Based Income pada PT Bank CIMB Niaga, Tbk selama empat tahun terakhir?

b. Bagaimana perkembangan penggunaan Transaksi Electronic Banking pada PT. Bank CIMB Niaga, Tbk selama empat tahun terakhir?

c. Bagaimana perkembangan pendapatan Fee Based Income pada PT. Bank CIMB Niaga, Tbk selama empat tahun terakhir?

\section{KAJIAN TEORI}

\section{Fee Based Income}

Fee Based Income sering disebut sebagai non interest income, yaitu sumber pendapatan bank selain pendapatan kredit dan securitas. Menurut SKAPI atau Standar Khusus Akuntansi Perbankan Indonesia, pendapatan fee based adalah imbalan yag diperoleh bank dari pemberian komitmen dan jasa-jasa lain diluar hasil yang diperoleh bank dari penanaman aktiva produktif, seperti kredit dan surat berharga. Dalam hal ini komisi dan provisi kredit dianggap sebagai hasil dari penanaman aktiva produktif sehingga tidak termasuk dalam Fee Based Income.

\section{Go Mobile}

Go Mobile, layanan mobile banking yang dapat memberikan kemudahan bagi para nasabah dalam bertransaksi, kapan saja dan di mana saja melalui smart phone. Dengan adanya perkembangan dan pembaharuan dari Go Mobile ini diharapkan dapat menjawab kebutuhan nasabah yang kian beralih ke digital banking dan sesuai dengan aspirasi CIMB Niaga menjadi perusahaan perbankan digital terdepan di Indonesia. 


\section{Rekening Ponsel}

Rekening Ponsel merupakan produk dengan layanan mutakhir yang mampu memberikan jasa finansial ke seluruh lapisan masyarakat, termasuk bagi yang tidak memiliki rekening bank sekalipun. Layanan ini merupakan yang pertama di Indonesia, rekening Ponsel memungkinkan nasabah untuk mentransfer uang ke nomor ponsel dari seluruh operator ponsel di Indonesia, menggunakan jenis ponsel apapun, dan yang paling utama adalah tidak memerlukan kartu ATM dan rekening bank.

\section{CIMB Clicks}

Sebuah layanan internet banking yang memungkinkan Nasabah untuk melakukan transaksi perbankan di mana saja dengan keamanan yang terjamin, dengan menggunakan captcha (kode alfanumerik acak) dan secure word (kode yang dibuat sendiri oleh pengguna) untuk menunjukkan bahwa Nasabah berada di situs yang benar milik CIMB Niaga.

\section{Penelitian Terdahulu}

Penelitian yang dilakukan oleh Pebriani Utaminingsih dan Lana Sularto (2015), Ibnu Permadi dan Nurdin (2017) bertujuan untuk menganalisis pengaruh transaksi Electronic Banking terhadap Fee Based Income. Berikut beberapa penelitian-penelitian terdahulu yang disajikan pada Tabel 1.

\section{Tabel 1}

Penelitian Terdahulu

\begin{tabular}{|c|c|c|c|}
\hline NO & PENELITIAN & JUDUL & HASIL PENELITIAN \\
\hline 1. & $\begin{array}{l}\text { Pebriani } \\
\text { Utaminingsih } \\
\text { dan Lana } \\
\text { Sularto } \\
(2015)\end{array}$ & $\begin{array}{l}\text { Pengaruh Transaksi } \\
\text { Electronic Banking } \\
\text { Terhadap Fee Based } \\
\text { Income pada PT. } \\
\text { Bank CIMB Niaga, } \\
\text { Tbk Periode 2010- } \\
2014\end{array}$ & $\begin{array}{l}\text { Penelitian ini didapatkan hasil bahwa } \\
\text { Transaksi E-Banking berpengaruh } \\
\text { secara positif dan signifikan terhadap } \\
\text { Fee Based Income. Hal ini terbukti } \\
\text { dengan Ho ditolak dan Ha diterima, } \\
\text { karena t tabel sebesar } 3,182 \text { dan thitung } \\
\text { sebesar 13,234 (t-hitung > t-tabel). } \\
\text { Hasil perhitungan korelasi product } \\
\text { moment sebesar 0,992 yang berarti } \\
\text { adanya hubungan yang sangat kuat dan } \\
\text { searah (positif) antara transaksi E- } \\
\text { Banking dan Fee Based Income. } \\
\text { Sedangkan korelasi determinasi } 98,3 \%\end{array}$ \\
\hline
\end{tabular}




\begin{tabular}{|c|c|c|c|}
\hline & & & $\begin{array}{l}\text { sedangkan sisanya } 1,7 \% \text { dipengaruhi } \\
\text { oleh faktor-faktor lain. }\end{array}$ \\
\hline 2. & $\begin{array}{l}\text { Ibnu Permadi } \\
\text { dan Nurdin } \\
(2017)\end{array}$ & $\begin{array}{l}\text { Pengaruh Transaksi } \\
\text { Electronic Banking } \\
\text { Terhadap Fee Based } \\
\text { Income pada PT } \\
\text { Bank Rakyat } \\
\text { Indonesia, Tbk dan } \\
\text { PT Bank CIMB } \\
\text { Niaga, Tbk Periode } \\
\text { 2012-2016 }\end{array}$ & $\begin{array}{l}\text { Penelitian ini didapatkan hasil, bahwa } \\
\text { berdasarkan keseluruhan pemaparan } \\
\text { analisis perhitungan statistik pada uji } \\
\text { korelasi, koefisien determinasi, dan uji } \\
\text { hipotesis, dapat diambil kesimpulan } \\
\text { bahwa transaksi Electronic Banking } \\
\text { pada PT Bank Rakyat Indonesia } \\
\text { memiliki pengaruh yang signifikan } \\
\text { terhadap variabel Fee Based Income } \\
\text { sebesar 95,063\%, sedangkan sisanya } \\
\text { sebesar 4,938\% dipengaruhi oleh faktor } \\
\text { lain yang tidak diamati. Transaksi } \\
\text { Electronic Banking PT CIMB Niaga } \\
\text { Tbk memiliki pengaruh 95,26\% } \\
\text { terhadap Fee Based Income sedangkan } \\
\text { sisanya sebesar 4,74\% berasal dari } \\
\text { faktor lain. }\end{array}$ \\
\hline
\end{tabular}

Sumber: Pebriani Utaminingsih dan Lana Sularto (2015), Ibnu Permadi dan Nurdin (2017)

\section{Kerangka Pemikiran Teoritis}

Secara skematis, kerangka pemikiran dapat digambarkan sebagai berikut:

\section{METODE}

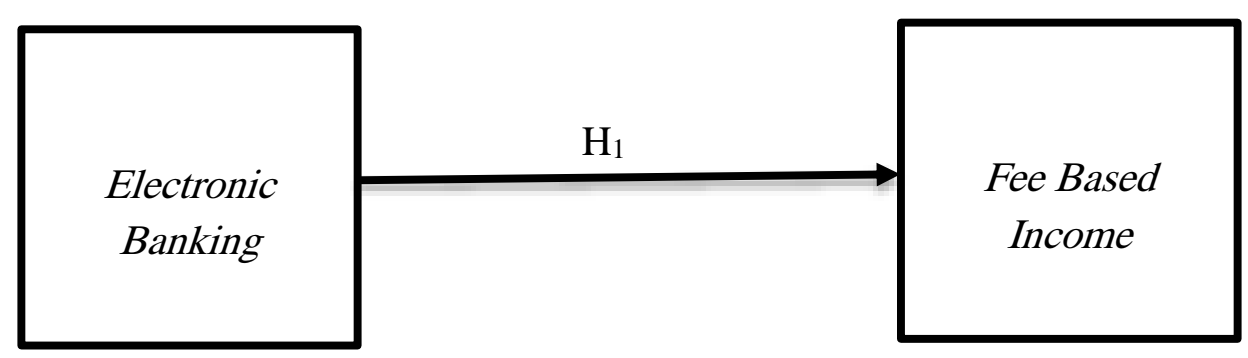

Gambar 1

Kerangka Pemikiran Teoritis

\section{Populasi dan Sampel}

Dalam penelitian ini, populasi yang digunakan adalah pendapatan Fee Based Income pada PT. Bank CIMB Niaga, Tbk periode 2014-2017.

Sampel yang digunakan dalam penelitian ini adalah produk transaksi Branchless Banking Rekening Ponsel, CIMB Clicks dan Go Mobile pada PT. Bank CIMB Niaga, Tbk. 


\section{Metode Pengumpulan Data dan Jenis Data}

Dalam penelitian ini metode pengumpulan data digunakan adalah studi pustaka dan dokumentasi. Studi Kepustakaan adalah teknik pengumpulan data dengan mengadakan studi penelaahan terhadap buku-buku, litertur-literatur, catatan-catatan, dan laporan-laporan yang ada hubungannya dengan masalah yang dipecahkan. Dalam penelitian ini metode yang digunakan adalah dengan menggunakan buku dan jurnal ilmiah, skripsi maupun tugas akhir yang berhubungan dengan judul penelitian. Teknik dokumentasi maksudnya adalah cara pengumpulan data yang diperoleh dari catatan (data) yang telah tersedia atau telah dibuat oleh pihak lain. Pengumpulan data yang dilakukan dalam penelitian ini adalah melihat, membaca dan mencatat data yang bersumber dari laporan keuangan publikasi Bank CIMB Niaga pada website bank yang bersangkutan atau melalui penelusuran pada laporan publikasi yang terdapat dalam website Otoritas Jasa Keuangan (OJK).

Jenis data penelitian ini adalah data sekunder yang diperoleh dari otoritas atau pihak yang mempunyai kewenangan. Penggunaan data ini mempunyai tingkat efisiensi yang lebih tinggi, meskipun kadang-kadang kurang akurat. Contohnya adalah data yang diperoleh dari hasil publikasi laporan tahunan perusahaan. Dalam penelitian ini data yang digunakan adalah data sekunder berupa Laporan Keuangan publikasi dari Bank CIMB Niaga Tahun 2014 - 2017.

\section{HASIL DAN PEMBAHASAN}

\section{Analisis Regresi Linier Sederhana}

Analisis ini bertujuan untuk mengetahui besarnya pengaruh perubahan variabel bebas pada variabel terikat. Hasil pengolahan atau output analisis regresi linier sederhana dapat dilihat pada tabel 2 berikut. 
Tabel 2

Hasil Analisis Regresi Linier Sederhana Coefficients $^{\mathrm{a}}$

\begin{tabular}{|c|c|c|c|c|c|c|}
\hline \multirow{2}{*}{\multicolumn{2}{|c|}{ Model }} & \multicolumn{2}{|c|}{$\begin{array}{l}\text { Unstandardized } \\
\text { Coefficients }\end{array}$} & \multirow{2}{*}{\begin{tabular}{|c|}
$\begin{array}{c}\text { Standardized } \\
\text { Coefficients }\end{array}$ \\
Beta \\
\end{tabular}} & \multirow[b]{2}{*}{$\mathrm{t}$} & \multirow[b]{2}{*}{ Sig. } \\
\hline & & B & Std. Error & & & \\
\hline & (Constant) & 2.752 & 426 & & 6.465 & .023 \\
\hline & $\begin{array}{l}\text { Transaksi E- } \\
\text { banking }\end{array}$ & .205 & .017 & 993 & 11.855 & .007 \\
\hline
\end{tabular}

a. Dependent Variable: Fee Based Income

Sumber: Data sekunder yang diolah dengan SPSS 16.0 for windows, Tahun 2018.

Berdasarkan tabel 2 diatas, maka disusun persamaan regresi linier:

$Y=2,752+0,205 X$

Berdasarkan persamaan garis regresi tersebut, maka dapat diartikan sebagai berikut:

a. Nilai konstanta (a) sebesar 2,752 yang dapat diartikan bahwa tanpa adanya Transaksi $E$ Banking (X=0), maka perkiraan Fee Based Income PT. Bank CIMB Niaga, Tbk sebesar Rp 2.752. Dengan asumsi, dengan tidak adanya transaksi elektronik banking (E-Banking) maka Fee Based Income bernilai positif, maka dengan adanya transaksi elektronik banking ( $E$ Banking), maka Fee Based Income bernilai positif.

b. Nilai koefisien regresi (b) sebesar 0,205 berarti setiap perubahan transaksi E-Banking sebesar 205 kali akan menambah Fee Based Income PT. Bank CIMB Niaga, Tbk sebesar Rp 1.000.000. Dengan asumsi, jika transaksi elektronik banking meningkat sebesar satu satuan, maka Fee Based Income akan meningkat sebesar 68.333 satuan.

\section{Analisis Koefisien Korelasi (Multiple R)}

Untuk mengetahui tingkat keeratan hubungan antara variabel Transaksi E-Banking (X) dengan variabel Fee Based Income (Y). Hasil pengolahan atau output dari Analisis Koefisien Korelasi dapat dilihat pada tabel 3 berikut: 
Tabel 3

Koefisien Korelasi

Model Summary

\begin{tabular}{|l|r|r|r|r|}
\hline Model & \multicolumn{1}{|c|}{$\mathrm{R}$} & R Square & Adjusted R Square & Std. Error of the Estimate \\
\hline 1 & $.993^{\mathrm{a}}$ & .986 & .979 & .44095 \\
\hline
\end{tabular}

a. Predictors: (Constant), Transaksi E-banking

Sumber: Data sekunder yang diolah dengan SPSS 16.0 for windows, Tahun 2018.

Nilai $\mathrm{r}_{\mathrm{xy}}$ adalah sebesar 0,993 atau 99,3\% menunjukkan hubungan antara Transaksi E-Banking dengan Fee Based Income PT. Bank CIMB Niaga, Tbk adalah sangat kuat dengan hubungan yang bersifat positif atau searah, dalam arti jika Transaksi E-Banking itu meningkat maka Fee Based Income akan meningkat dan sebaliknya.

\section{Analisis Koefisien Determinasi ( $R$ Square)}

Untuk mengetahui seberapa besar pengaruh variabel-variabel bebas terhadap variabel terikat. Hasil pengolahan atau output dari Analisis Koefisien Determinasi dapat dilihat pada tabel 4 berikut:

\section{Tabel 4}

\section{Koefisien Determinasi}

Model Summary

\begin{tabular}{|l|r|r|r|r|}
\hline Model & \multicolumn{1}{|c|}{$\mathrm{R}$} & R Square & Adjusted R Square & Std. Error of the Estimate \\
\hline 1 & $.993^{\mathrm{a}}$ & .986 & .979 & .44095 \\
\hline
\end{tabular}

a. Predictors: (Constant), Transaksi E-banking

Sumber: Data sekunder yang diolah dengan SPSS 16.0 for windows,Tahun 2018.

Dari tampilan outputSPSS model summary besarnya adjusted $\mathrm{R}^{2}$ adalah 0,979 , hal ini berarti 97,9\% variabel Transaksi E-Banking berpengaruh signifikan terhadap Fee Based Income. Sedangkan sisanya $(100 \%-97,9 \%=2,1 \%)$ dipengaruhi oleh faktor lain.

\section{Pengujian Hipotesis Parsial (Uji t)}

Hipotesis yang akan diuji adalah sebagai berikut: 
1. $\mathrm{H}_{0}: \beta=0$ Tidak terdapat pengaruh yang positif dan signifikan transaksi $E$-Banking terhadap Fee Based Income PT. Bank CIMB Niaga, Tbk.

2. $\mathrm{H}_{\mathrm{a}}: \beta \neq 0$ Terdapat pengaruh yang positif dan signifikan transaksi E-Banking terhadap Fee Based Income PT. Bank CIMB Niaga, Tbk.

3. Untuk mencari tabeldigunakan taraf nyata $(\alpha)=5 \%$ atau tingkat keyakinan $(1-\alpha)=1-5 \%=95 \%$ karena dengan semakin besar tingkat kepercayaan maka akan semakin akurat hasil yang diperoleh.

4. Statistik uji $\mathrm{t}$

\section{Tabel 5 \\ Uji t}

Coefficients $^{\mathrm{a}}$

\begin{tabular}{|l|r|r|r|r|r|}
\hline \multirow{2}{*}{ Model } & \multicolumn{2}{|c|}{$\begin{array}{c}\text { Unstandardized } \\
\text { Coefficients }\end{array}$} & $\begin{array}{c}\text { Standardized } \\
\text { Coefficients }\end{array}$ & & \\
\cline { 2 - 5 } & \multicolumn{1}{|c|}{ B } & Std. Error & \multicolumn{1}{c|}{ Beta } & \multicolumn{1}{c|}{ S } & \multicolumn{1}{c|}{ Sig. } \\
\hline $\begin{array}{l}\text { (Constant) } \\
\begin{array}{l}\text { Transaksi E- } \\
\text { banking }\end{array}\end{array}$ & 2.752 & .426 & & 6.465 & .023 \\
& .205 & .017 & .993 & 11.855 & .007 \\
\hline
\end{tabular}

a. Dependent Variable: Fee Based Income

Sumber: Data sekunder yang diolah dengan SPSS 16.0 for windows,Tahun 2018.

Berdasarkan tabel diatas, maka hasil pengolahan data diperoleh thitungsebesar 11,855.

5. Dari hasil pengolahan SPSS di atas didapat nilai thitung sebesar 11,855. Dengan alpha $(\alpha)=5 \%$ dan $\mathrm{df}=\mathrm{n}-\mathrm{k}=2$, maka berdasarkan tabel distribusi $\mathrm{t}$ dua pihak didapat nilai $\mathrm{t}_{\text {tabel }}$ sebesar 4,302. Nilai thitungdan tabel tersebut kemudian diuji menggunakan kriteria pengujian sebagai berikut:

Jika $t_{\text {hitung }} \geq \mathrm{t}_{\text {tabelatau }}-\mathrm{t}_{\text {hitung }} \leq-\mathrm{t}_{\text {tabel }}$, maka $\mathrm{H}_{0}$ ditolak.

Jika $\mathrm{t}_{\text {hitung }}<\mathrm{t}_{\text {tabelatau }}-\mathrm{t}_{\text {hitung }}>-\mathrm{t}_{\text {tabel }}$, maka $\mathrm{H}_{0}$ diterima.

Berdasarkan hasil tersebut nilai thitunglebih besar dari pada tabel $(11,855>4,302)$ maka $H_{0}$ ditolak dan $\mathrm{H}_{2}$ diterima. Artinya terdapat pengaruh yang signifikan antara transaksi elektronik Banking (E-Banking) terhadap Fee Based Income, dengan kata lain kita dapat mempercayai bahwa 95\% transaksi elektronik Banking (E-Banking) berpengaruh terhadap Fee Based Income pada PT Bank CIMB Niaga, Tbk 


\section{Perkembangan Transaksi Electronic Banking}

Perkembangan Transaksi Electronic Banking dihitung dengan indeks rata-rata tidak tertimbang. Hasil pengolahan atau output dapat dilihat dalam tabel 6 di bawah ini:

\section{Tabel 6}

Perkembangan Transaksi Electronic Banking

\begin{tabular}{|c|c|c|c|}
\hline Tahun & $\begin{array}{c}\text { Transaksi } \\
\text { Electronic Banking } \\
\text { (Juta Rupiah) }\end{array}$ & $\begin{array}{c}\text { Indeks } \\
\text { Perkembangan } \\
(\%)\end{array}$ & $\begin{array}{c}\text { Naik / } \\
\text { Turun } \\
(\%)\end{array}$ \\
\hline 2014 & 2.513 .000 & 0 & 0 \\
\hline 2015 & 3.800 .000 & 151,21 & 51,21 \\
\hline 2016 & 4.768 .000 & 125,47 & 25,47 \\
\hline 2017 & 6.379 .360 & 133,80 & 33,80 \\
\hline
\end{tabular}

Berikut ini grafik perkembangan Transaksi Electronic Banking yang terjadi selama empat tahun dari tahun 2014-2017:

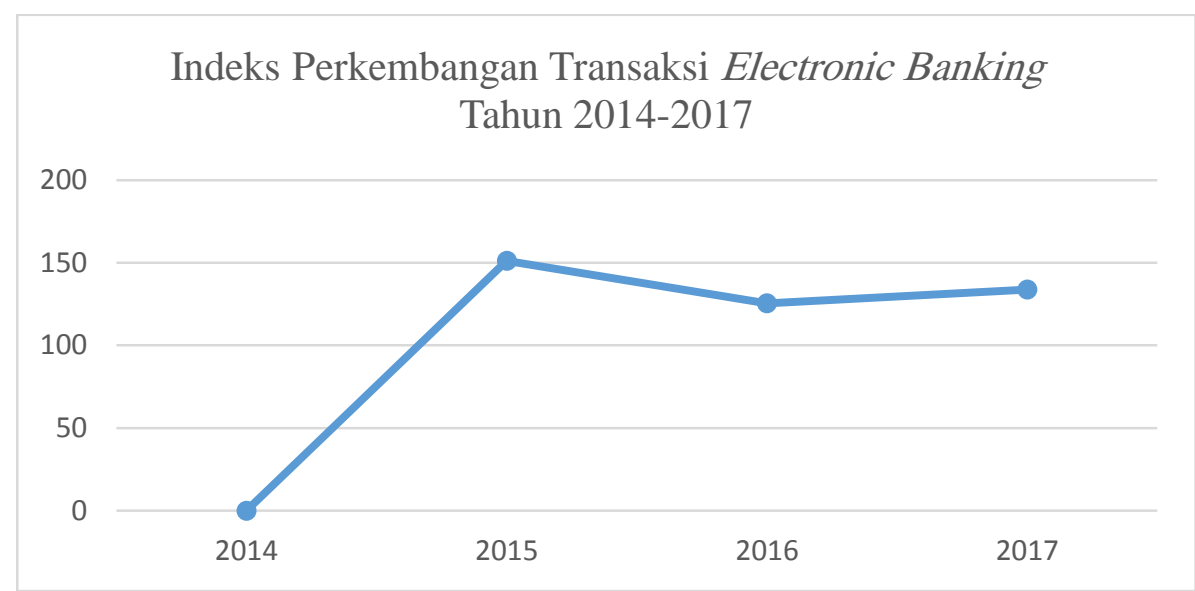

Gambar 2

\section{Grafik Indeks Perkembangan Transaksi Electronic Banking Tahun 2014-2017}

Berdasarkan gambar di atas, dapat dilihat bahwa transaksi Electronic Banking mengalami fluktuasi naik turun. Dan sempat mengalami penurunan transaksi yang sangat drastis di tahun 2016 sebesar 25,47\%. Nasabah lebih memilih melakukan transaksi langsung melalui bank. Hal ini berdampak pada pendapatan bank, tetapi pendapatan bank masih dapat diselamatkan apabila jumlah nasabah yang melakukan transaksi di bank lebih banyak dibanding melalui digital Banking. 


\section{Perkembangan Pendapatan Fee Based Income}

Perkembangan Pendapatan Fee Based Income dihitung dengan indeks angka tidak tertimbang. Hasil pengolahan atau output dapat dilihat dalam tabel 7 di bawah ini:

\section{Tabel 7}

Perkembangan Pendapatan Fee Based Income

\begin{tabular}{|r|c|r|r|}
\hline Tahun & $\begin{array}{c}\text { Pendapatan Fee } \\
\text { Based Income }\end{array}$ & \multicolumn{1}{|c|}{$\begin{array}{c}\text { Indeks } \\
\text { Perkembangan } \\
(\%)\end{array}$} & $\begin{array}{c}\text { Naik / } \\
\text { Turun (\%) }\end{array}$ \\
\hline 2014 & 1.980 .000 & 0 & 0 \\
\hline 2015 & 2.348 .043 & 118,59 & 18,59 \\
\hline 2016 & 2.820 .000 & 120,10 & 20,10 \\
\hline 2017 & 3.300 .000 & 117,02 & 17,02 \\
\hline
\end{tabular}

Berikut ini grafik perkembangan pendapatan Fee Based Income yang terjadi selama empat tahun dari tahun 2014-2017:

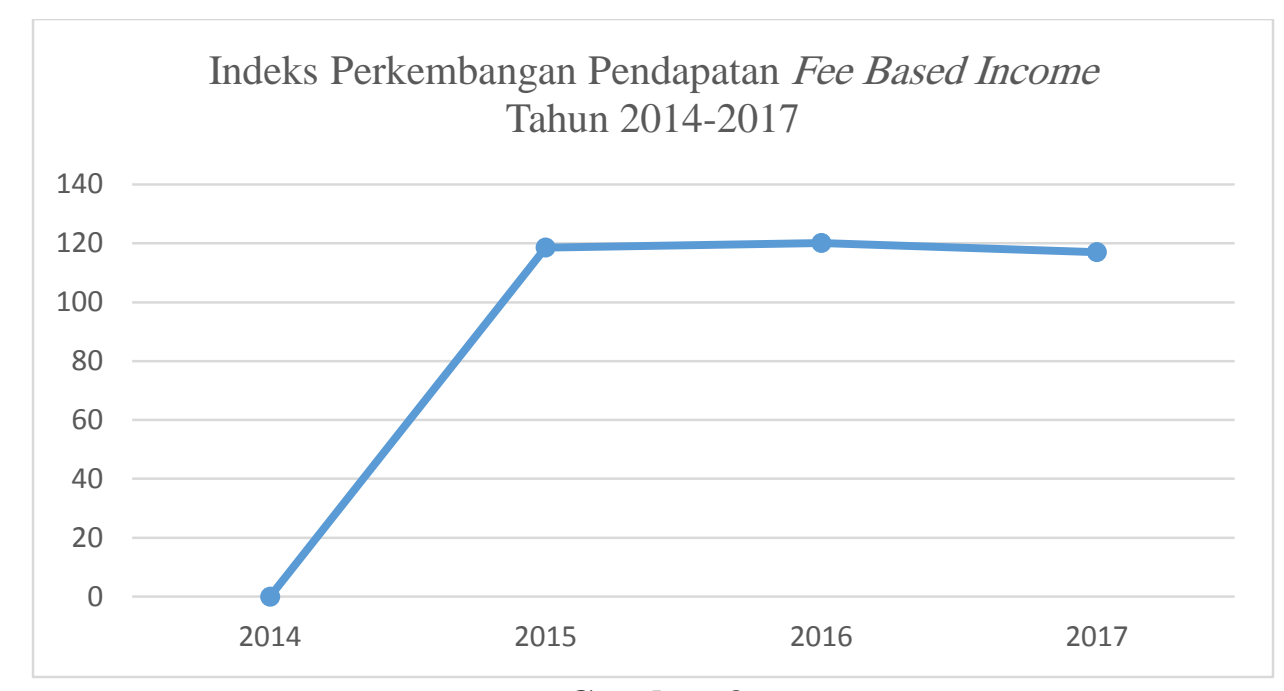

Gambar 3

Indeks Perkembangan Pendapatan Fee Based Income Tahun 2014-2017

Berdasarkan gambar di atas pendapatan fee based income Bank CIMB Niaga mengalami fluktuasi dari tahun ke tahun. Sempat mengalami peningkatan walaupun tidak terlalu besar di tahun 2016 sebesar 20,10\% dibanding tahun 2015 sebesar 18,59\%. Tetapi mengalami penurunan di tahun 2017 yang dikarenakan kurangnya minat nasabah dalam melakukan transaksi melalui digital banking. Hal ini dikarenakan pendapatan bank paling besar dari adanya transaksi digital Banking yang dilakukan nasabah. 


\section{PENUTUP}

\section{Kesimpulan}

Kesimpulan dari penelitian ini adalah sebagai berikut:

1. Transaksi E-Banking berpengaruh secara positif dan signifikan terhadap Fee Based Income. Hal ini dapat dilihat pada hasil pengujian hipotesis yang menolak H0 dan menerima Ha. Dapat disimpulkan bahwa terdapat pengaruh positif yang signifikan transaksi E-Banking terhadap Fee Based Income pada PT. Bank CIMB Niaga, Tbk. Hal ini terbukti dengan H0 ditolak dan Ha diterima, karena $\mathrm{t}$ tabel sebesar 4,302 dan $\mathrm{t}$ hitung sebesar 11,855 ( $\mathrm{t}$ hitung $>\mathrm{t}$ tabel). Hasil perhitungan korelasi productmoment sebesar 0,993 yang berarti adanya hubungan yang sangat kuat dan searah (positif) antara transaksi E-Banking dan Fee Based Income. Sedangkan korelasi determinasi 97,9\%, sedangkan sisanya 2,1\% dipengaruhi oleh faktorfaktor lain.

2. Berdasarkan perhitungan statistik deskriptif data penelitian, diperoleh bahwa variabel transaksi Electronic Banking mengalami fluktuasi atau naik turun setiap tahunnya. Dari periode 2014 sampai 2017 transaksi Electronic Banking PT. Bank CIMB Niaga, Tbk mengalami kenaikan tertinggi pada periode tahun 2015 dan kenaikan terendah pada tahun 2017.

3. Berdasarkan perhitungan perkembangan data penelitian, diperoleh bahwa variabel transaksi Fee Based Income mengalami fluktuasi atau naik turun setiap tahunnya. Dari periode 2014 sampai 2017 transaksi Fee Based IncomePT. Bank CIMB Niaga, Tbk mengalami penurunan pada periode tahun 2016 .

4. Dari ketiga kesimpulan di atas maka dapat dilihat rata - rata kenaikan selama periode 2014 - 2017 dari Transaksi Electronic Banking sebesar 41,81\% dan Fee Based Income sebesar $14,36 \%$.

\section{Keterbatasan Penelitian}

Dalam penelitian ini, terdapat beberapa kekurangan dan keterbatasan yang merupakan kelemahan dalam penelitian ini, di antaranya: 
1. Penelitian ini terbatas pada PT Bank CIMB Niaga, Tbk saja yang berarti penelitian ini hanya boleh digunakan untuk Bank CIMB Niaga saja.

2. Keterbatasan waktu dan tenaga yang dimiliki oleh peneliti, maka penelitian ini menggunakan sampel produk Transaksi Branchless Banking atau Electronic Banking Rekening Ponsel, Go Mobile, dan CIMB Clicks pada PT. Bank CIMB Niaga, Tbk yang memenuhi kriteria sampel penelitian.

3. Keterbatasan biaya yang dimiliki oleh peneliti, maka dalam penelitian ini terfokus pada transaksi E-Banking yang mempengaruhi Fee Based Income.

4. Dalam penelitian ini terbatas pada alat statistik SPSS 16.0.

\section{Agenda Penelitian Mendatang}

Berdasarkan keterbatasan penelitian yang ada, maka penulis dapat menyarankan beberapa hal untuk penelitian mendatang sebagai berikut:

1. Diharapkan penelitian yang akan datang, sampel yang digunakan lebih banyak sehingga hasil analisis dari penelitian yang didapatkan akan lebih akurat.

2. Penelitian mendatang sebaiknya lebih memperhatikan sub indikator yang lain dari $E$ Banking yang digunakan untuk melakukan pengukuran Fee Based Income sehingga diharapkan dapat meneliti faktor peningkatan dan penurunan Fee Based Income yang lainnya.

3. Penelitian ini menggunakan terbatas pada alat statistik SPSS 16.0, maka penulis menyarankan agar penelitian selanjutnya menggunakan alat statistik SPSS dengan versi yang lebih tinggi atau bahkan bisa menggunakan alat statistik eviews ataupun yang lainnya.

\section{DAFTAR PUSTAKA}

Amelia, Riska. 2012. Pengaruh Transaksi E-Banking Terhadap Fee Based Income pada PT. Bank BNI, Tbk. Jakarta: Skripsi STEI.

Anggadini, Sri Dewi, 2010. Analisis Fee Based Income Dampaknya Terhadap Profitabilitas: Studi Kasus pada PT. Bank Negara Indonesia(Persero), Tbk, Jurnal Bisnis, Manajemen \& Ekonomi, Vol.9, No.9: 2196-2308. 
Aprillya, Shella Fitri. 2013. Pengaruh Fee Based Income Terhadap Tingkat Return On Assets (ROA): Studi Pada Perbankan BUMN Yang Terdaftar di Bursa Efek Indonesia. Bandung: Skripsi Universitas Pasundan.

Bank Indonesia, 1998. Undang - Undang No. 10 Tahun 1998 tentang Perbankan. Jakarta.

CIMB Niaga. 2014. Laporan Tahunan. www.cimbniaga.com

CIMB Niaga. 2015. Laporan Tahunan. www.cimbniaga.com

CIMB Niaga. 2016. Laporan Tahunan. www.cimbniaga.com

CIMB Niaga. 2017. Laporan Tahunan. www.cimbniaga.com

Dajan, Anto. 1986. Pengantar Metode Statistik. Jakarta.

Dewi, Dwastrarini Yuliana Candra dan Hadri Kusuma, 2005. Analisis Proporsi Perolehan Fee Based Income Bank Pembangunan Daerah (BPD) Di Indonesia Periode 1999-2003, Jurnal Sinergi. Kajian Bisnis dan Manajemen. Edisi Khusus on Finance: 85-97.

Ghozali, Imam. 2009. Aplikasi Analisis Multivariate Dengan Program SPSS. Semarang : Badan Penerbit Universitas Diponegoro.

Permadi, Ibnu dan Nurdin. 2017. Pengaruh Transaksi E-Banking Terhadap Fee Based Income di PT. Bank Rakyat Indonesia (Persero), Tbk dan PT Bank CIMB Niaga, Tbk. Jurnal Akuntansi.

Pradhana Riza Anantya. 2008. Analisis Kinerja Bank - bank yang Menggunakan Internet Banking di Indonesia. Jakarta: Skripsi FEUI.

Sathye, Milind. 2005. The impact of internet Banking on performance and rial profil : Evidence from Australian Credit union, Jurnal of Banking Regulation.

Sawitri Peni, dan Eko Hartanto. 2007. Bank dan Lembaga Keuangan Lain. Jakarta: Gunadarma.

Sugiarto, Agung. 2012. Adopsi Internet Banking Bagi Keunggulan Performa Perbankan: Sebuah Studi pada Sektor Perbankan di Indonesia, Jurnal Dinamika Akuntansi, Vol.4, No.1: 13-19.

Sugiyono. 2007. Metode Penelitian Bisnis. Bandung: CV Alfabeta.

Suprapto J. 2008. Statistik: Teori dan Aplikasi. Jakarta: PT.Gelora Aksara Pratama. 
keunis Majalah Ilmiah - ISSN No 2302-9315 Vol. 7 No 1 Thn VII Januari 2019

Utaminingsih, Pebriani dan Lana Sularto. 2015. Pengaruh Transaksi E-Banking Terhadap Fee Based Income pada PT. Bank CIMB Niaga, Tbk. Jurnal Akuntansi.

Wiji Nurastuti. 2011. Teknologi Perbankan. Edisi Pertama, Cetakan Pertama. Yogyakarta: Graha Ilmu.

Y. Sri Susilo dkk. 2008. Bank dan Lembaga Keuangan Lainnya, cetakan pertama, Jakarta: Salemba Empat. 